\title{
Employee Perceptions of Board Effectiveness in a State Owned Medical Aid Society in Zimbabwe
}

\author{
Shepherd Chinyoka ${ }^{1}$, Kudakwashe Sithole ${ }^{2}$ \\ ${ }^{\& 2}$ Zimbabwe Open University, Harare, Zimbabwe
}

\begin{abstract}
The research study was aimed at assessing employee perceptions of board effective in state enterprises using in a public sector medical aid institution in Zimbabwe. The objectives of the study were to assess how employees at PSMAS perceive board effective in state owned medical aid society. A case study approach was used. Quantitative design was used with a sample of sample size of 80 employees of the medical aid society. Simple random sampling technique was used. The major findings of the study were that employees were satisfied with the process used to appoint board members, perceived board as members lacking skills and experience required to deal with board issues. Further, the results reflected that employees perceived the board as lacking diversity coupled with a lack of understanding of the knowledge of the sector in which the organisation operates. The study recommended that board members must devote considerable time to company board duties as well as crafting a framework of internal controls. However, the results obtained cannot be generalised to all state owned enterprises and should not be viewed as conclusive but should be regarded as a guide for further studies on the topic in other enterprises.
\end{abstract}

\section{Introduction}

There has been an increasing interest in exploring effectiveness of boards of directors and corporate performance since the collapse of a sizeable number of companies especially in the US and UK. Kirkpatrick (2009) posits that the response of many governments to the collapse of companies through introduction the world over of changes that were incremental which changes was targeted at the countries' financial markets. While there are a number of studies in the developed economies concerning the different aspects of corporate governance, the same cannot be said about the developing economies in the field of corporate governance. Flora (2006) highlights that the investigation of corporate governance practices in emerging financial markets of the world is of greater significance let alone necessity because these markets differ from those of the developed world in terms of their cultural, social, and economic variables.

The emerging markets differ markedly from the developed markets in terms of the contextual settings. This has resulted in results drawn from research conducted in the developed world. Classen and Fan in Manawaduge (2012) state that their research reveals that most Asian markets have systems of governance that are characterised by weak institutions and poor property rights. This supports the argument that conventional corporate governance has limited effectiveness in economies. Zimbabwean corporate governance in state institutions has become a far cry. Directors in state institutions are pocketing hefty salaries and perks to the detriment of service delivery (Ndlovu, 2010). Ndlovu (2010) supported by Zhou (2012) suggest that state institutions have been decimated by the level of corruption which has seen the companies being reduced to "harvesting rods and tools of institutionalised predation". This implies that additional research is needed on corporate governance problems associated with the principal-agency problem.

\section{Methodology}

This study was based on a case study of a state owned medical aid society. Creswell (2013) defined a case study as an account of an activity, event or problem that contains a real or hypothetical situation and includes the complexities you would encounter in the workplace. Case studies are used to help you see how the complexities of real life influence decisions. In this study the population comprised of employees of the state owned medical aid society in Harare. The study population constituted of management and employees of the medical aid all of them totaling 80 . The researcher used probability sampling techniques, specifically simple random sampling. Names of the employees were placed in a hat where a name was withdrawn on after the other without replacement until the desired sample size was enough. The sample comprised of ten (10) managers and seventy (70) general employees. The sample was selected by drawing random employee numbers using a computer. The tools used in the research were the questionnaire. Statistical Package for Social Sciences was used for the analysis of data. Descriptive statistics were used to report findings. 


\section{Results and Discussion}

The process of board member appointment satisfies me

From the study, $48 \%$ of the total respondents agree and strongly agree that the process of board member appointment satisfies me. Of the total respondents, $20 \%$ disagree that the process of board member appointment satisfies me, while $14 \%$ strongly disagreed. On the other hand, $18 \%$ of the respondents do not know whether the process of board member appointment satisfies me or not. This therefore shows that the majority of the respondents believe that the process of board member appointment is satisfactory.

\section{The board members have sufficient skills, experience, time and resources to conduct their duties.}

There is a weak consensus that the board members have sufficient skills, experience, time and resources to conduct their duties as shown in histogram with $28 \%$ of the respondents agreeing and strongly agreeing with the notion. Some respondents who expressed their reservations to this notion constituted $25 \%$ and $18 \%$ hold that the board members have no sufficient skills, experience, time and resources to conduct their duties. The remaining $28 \%$ do not see a difference.

\section{The board members have sufficient diversity in terms of experience, balance between executive and non-} executive directorships.

The research shows that $6 \%$ of the total respondents are of the view that the board members have sufficient diversity in terms of experience, balance between executive and non-executive directorships while $14 \%$ added their voice by agreeing with the statement. On the other hand $32 \%$ hold the optimistic view that have no sufficient diversity in terms of experience, balance between executive and non-executive directorships, while $23 \%$ were strongly disagreeable and a mere $25 \%$ are undecided. This contradicts the findings by Gurgler (2010) that a board of directors should have a balance in terms of skills, experience and balance in terms of executive and non-executive directorships. He further argues that executive directors should be independent. Tirole (2012) argues that "the board and its committees should have the appropriate balance of skills, experience, independence and knowledge of the firm to enable them to discharge their respective duties and responsibilities effectively."

\section{Directors have a sufficient understanding of the organisation and the sector in which it operates.}

Figure 4.6 shows that $21 \%$ of the respondents agreed that the directors have a sufficient understanding of the organisation and the sector in which it operates, $15 \%$ were undecided while another $64 \%$ disagreed. The directors are better when they understand the operations of the business and the industry (Tirole, 2009). The results therefore do not support the findings of researchers such as Tirole (ibid). Of the total respondents $83 \%$ have declined that the board has a set of objectives in place that seek to enhance the effectiveness of board activities. Only $11 \%$ agreed that the board has a set of objectives in place that seek to enhance the effectiveness of board activities. Objectives are the source of direction to management. Coyle (2006) posits that different companies have different objectives and he further argues that whatever the objectives, the directors have participate in their setting and then monitor the implementation. The results thus do not reflect this understanding.

\section{The board's workload is effectively dealt with by the board acting collectively.}

The greater proportion of the respondents believes that the board's workload is effectively dealt with by the board acting collectively; these constitute $51 \%$. Those in support that the board's workload is effectively dealt with by the board acting collectively will provide the confidence in the company's performance. The remaining $45 \%$ are divided between not supporting the board's workload is effectively dealt with by the board acting collectively and simply being indecisive. Of the respondents $19 \%$ were undecided while $20 \%$ disagreed and 6\% strongly disagreed. The Higgs Report (2003) and the Cadbury Report (1992) all provide that the directors of the company should work and make decisions about the issues that would the company collectively. They further provide that directors should hold frequent board meetings to make decisions as a collective team rather than to allow a few individual persons or group of persons to control decisions that would affect the company.

\section{The frequency of board meetings enhances effectiveness.}

Results show that the greater proportion of $82 \%$ of the respondents agreed that the frequency of board meetings enhances effectiveness. Those not in supports make up $10 \%$ and $8 \%$ are of the opinion that the frequency of board meetings do not enhances effectiveness. Board diversity in composition is an important feature and driver of board effectiveness as argued by Abben (2011). 


\section{Timeliness and appropriateness of ongoing professional development received by board members is satisfactory.}

An analysis of the results from Figure 4.7 reflected that $81 \%$ of the respondents agreed that timeliness and appropriateness of ongoing professional development received by board members is satisfactory, $15 \%$ were neutral while another $4 \%$ were strongly disagree. The directors receive appropriate ongoing professional development which is healthy with regards to improving director competence. The table 4.8 shows that $19 \%$ agreed that the company provides training to directors to enhance their performance. The greater proportion of $81 \%$ were not in support of the company provides training to directors to enhance their performance. Training of directors can be aligned with induction of the directors. Coyle (2006) posits that directors require effective induction to enhance their effectiveness.Employees showed mixed responses to the statement regarding whether board members had opportunities of attending formal courses, conferences and seminars. The results analysed indicated that $28 \%$ of the respondents agreed that the board members were afforded an appropriate opportunity, $6 \%$ were neutral, and $45 \%$ disagreed while the remaining $21 \%$ strongly disagreed. The majority of the respondents $(66 \%)$ disagreed with the statement. Board members need to regularly attend refresher courses including formal conferences on areas such as developments in corporate governance, strategic management and statutory requirements for the board of directors (Ncube et al, 2012). They argue that that attendance of these programmes enhances board members' understanding of the corporate governance issues.

The Stewardship defines situations in which managers are not motivated by individuals' goals but rather see themselves as steward seeking to attain the objectives of the organisation which will in turn benefit all the other stakeholders in the business (Gill and Marthur, 2011). Directors are the stewards of the company according to the stewardship theory. The results indicate that $74 \%$ of the respondents agree that the board of directors of PSMAS understand their stewardship role as well as fulfilling that role. The other $4 \%$ agree, while $11 \%$ disagree with the statement. The remaining $11 \%$ were neutral regarding the statement. The findings support the directors' stewardship role in an organization.

\section{The board understands the company's internal control framework.}

A control framework is a data structure that organizes and categorizes an organization's internal controls, which are practices and procedures established to create business value and minimize risk (Tirole, 2009). Various code of corporate governance recommend that directors should be the custodians of the assets of the company and are the ones responsible of putting in place a system of internal controls to protect the assets of the company. However, the finding of the research show that $34 \%$ of the respondents disagreed with the statement that the board understand the company's internal control framework, $27 \%$ strongly agree, while $18 \%$ were neutral. The remaining $16 \%$ agree while the other $5 \%$ strongly agreed. The results therefore contradict the assertions of Tirole (2009) that the board should shape the company's internal control framework.

The performance of an organization can be measured using either financial measures such as the use of financial ratios or the non-financial measures such as the balanced scorecard (Johnson and Scholes, 2008). On this measure, the respondents reflected that $20 \%$ agreed that both financial and non-financial measures are used, $35 \%$ of the respondents disagreed while $35 \%$ were neutral. The results were not in agreement with the assertions of Jonson and Scholes (2008). Adequate measurement of the managerial performance is necessary to ensure the attainment of objectives by the organization as well as to meet the expectations of shareholders. The King III Report (2009) provides that directors and management contracts should be based on the performance of the directors as reflected by the performance of the organizations. The CEO's remuneration should be linked to the performance of the company (Gill and Marthur (2011). The findings of the research reflected that $5 \%$ of the respondents strongly agreed, $69 \%$ agreed, while $21 \%$ were neutral. The remaining $5 \%$ strongly disagree with the statement that management's remuneration was appropriately linked to the performance of the organization and to comparable companies.

\section{Board has an agreed process to support the CEO adequately.}

The Chief Executive Officer is the head of executive management and an ex-officio member of the board of directors. The board delegates some of its management responsibilities to CEO (Gurgler, 2010). The analysed data on the point whether the board has an agreed process to support the CEO adequately, the results showed that $84 \%$ disagreed with the statement, $10.0 \%$ agree with the statement while $6 \%$ strongly agreement. The results reflect a board not working with the chief executive officer.

\section{Directors have a sufficient understanding of the organisation and the sector in which it operates.}

Figure 4.6 shows that $21 \%$ of the respondents agreed that the directors have a sufficient understanding of the organisation and the sector in which it operates, $15 \%$ were undecided while another $64 \%$ disagreed. The directors are better when they understand the operations of the business and the industry (Tirole, 2009). The results therefore do not support the findings of researchers such as Tirole (ibid). 


\section{Conclusion}

Employee perceptions about the effectiveness of the board of directors are often an ignored section in academic research as this is usually difficult to quantify in concrete terms. Board effectiveness is the most difficult aspect in corporate governance assessment. The findings of the study indicated that employees were satisfied with the process of board appointments, and board members lacked the sufficient skills and experience to deal with board issues. There is also lack of diversity regarding the proportions of non-executive directors and executive directors. The directors lack an appreciable understanding of the medical sector. However, board members exhibit a high degree of integrity in dealing with board issues.

\section{References}

[1]. Alreck, P.L. \& Settle, R.B. (1995).The Survey Research Handbook.(2nd Ed.). Burr Ridge: Irwin Baker, R. (2008) Institute of Directors. Pall Mall, London SW1Y.

[2]. Bebchuck, L. \& Hamdani, A. (2009).The Elusive Quest for Global Governance Standards. Harvard Law School, Discussion Paper Series No. 63 .

[3]. Berger, A.N., Clarle, R., Kappler, L., \& Udell, G.F. (2005).Corporate Governance and Bank performance: a joint analysis of static, selection and dynamic Effect of domestic, foreign, \& state ownership. The World Bank, Policy Research Paper.

[4]. Bryman, A. (2011). Research Methods and Organization Studies. London: Unwin Hyman Coldwell, D. \& Herbst, F. (2009).Business Research, Cape Town: Juta \& Co. Ltd.

[5]. Collis, J. and Hussey, R. (2003).Business Research: A Practical Guide for Undergraduate and Postgraduate Students. (2nd Ed.) Basingstoke: Palgrave McMillan.Consumer Service, 24-34.

[6]. Cooper and Schindler, P. S. (2011).Business Research Methods.(11 ${ }^{\text {th }}$ Ed).New York:Cooper, S. (2006). Corporate Social Performance: A Stakeholder Approach. Ashgate Publishing, Ltd.

[7]. Coyle, B. (2006). Corporate Governance: Professional Development. ICSA: London.

[8]. Creswell, J. (2013). Research Design: Quantitative and Qualitative Approach. (2 ${ }^{\text {nd }}$ Ed) Thousand Oaks: Sage.

[9]. Dalton, D., \& Kesner, I. (1987).Composition and CEO Duality in Boards of Directors: An International Perspective. Journal of International Business Studies, 18(3), 33-42.

[10]. Dellinger, A. (2005). Validity and the Review of Literature Research in Schools. 12(2), 41-54.

[11]. Easterby-Smith, M. Thorpe, R. and Lowe, A. (2010). Management Research: An Economics of Business, 10, $261-289$.

[12]. Geiger, S. (2012). "Exploring right-time shopping behaviour."Journal of Retailing and Gill, A., \& Mathur, N. (2011).Board Size, CEO Duality, and the Value of Canadian Manufacturing Firms. Journal of Applied Finance and Banking, 1(3), 1-13.

[13]. Gillan, S. L. (2006). Recent Developments in Corporate Governance: An Overview. Journal of Corporate Finance, 12(3), $381-402$.

[14]. Green, B.N., Johnson, C.D. and Adam, A. (2006). Writing Narrative Literature Reviews for peer reviewed journals: Secrets of the Trade. Journal of Chiropractic Medicine. 5(3), 101-114.

[15]. Gronbjerg, K. A. (2010). The U.S. nonprofit human service sector: A creeping revolution. In Hasenfeld, Y. (Ed.), Human services as complex organizations, 79-96).

[16]. Gugler, K. (2010). Corporate governance and investment. International Journal of the Haque, F., Arum, T. \& Kirkpatrick, C. (2006). Corporate Governance and Capital Markets: A Conceptual Framework.

[17]. Hasenfeld, Y. (2010). The Attributes of Human Service Organizations, 9-32.

[18]. Hillman, A. J., \& Dalziel, T. (2003). Boards of Directors and Firm Performance: Integrating Agency and Resource Dependence Perspectives. Academy of Management Review, 28(3), 383-396.

[19]. Hillman, A. J., Cannella, A. A., \& Paetzold, R. L. (2011).The Resource Dependence Role of Corporate Directors: Strategic Adaptation of Board Composition in Response to Environmental Change. Journal of Management Studies, 37(2), 235-256.

[20]. Ncube, F. and Maunganidze, L. (2012). Corporate Governance and Executive Compensation in Zimbabwean State Owned Enterprises: A Case of Institutionalized Predation, Management Journal, 4 (6), 131-140.

[21]. Peng, M. W., Li, Y., Xie, E., \& Su, Z. (2010). Ceo Duality, Organizational Slack, and Firm Performance in China. Asia Pacific Journal of Management, 27(4), 611-624.

[22]. Khan, A., \&Awan, S. (2012). Effect of Board Composition on Firm's Performance: A Case of Pakistani Listed Companies. Interdisciplinary Journal of Contemporary Research in Business, 3(10), 853-863.

[23]. Kothari, C. R. (2012). Research Methodology and Technique. New Delhi: New Age Leedy, P. D. and Ormrod, J. E. (2010). Practical Research: Planning and Design $\left(8^{\text {th }}\right.$ Ed). Loue, S., and Case, S.L. (2011). Textbook of research ethics: Theory and practice. New York: Plenum Press.

[24]. Ogbechie, C (2012): Corporate Governance A Challenge For Nigerian Banks. [Online] [Retrieved on 17/09/16] from http://www.businessdayonline.com.

[25]. Pagano, M., \& Volpin, P. (2005).The Political Economy of Corporate Governance. The American Economic Review. 95(4)10051030

[26]. Rathore, J.A. (2005). An OECD Perspective on Corporate Governance and Ownership Structure in India. Aarhus School of Business: Denmark.

[27]. Razaee, Z. (2009). Corporate Governance \& Ethics. John Wiley \& Sons. New Jersey: USA Razaee, Z. (2007). Corporate Governance Post Sarbanes-Oxley: Regulations.Requirements and Integrated Processes. New Jersey: USA

[28]. Sim, M. (Ed.). (2010). Ethics of Scientific research. Lanham, MD: Rowan and Littlefield.

[29]. Stanley, B., Sieber, J.E., \& Melton, G.B. (Ed.). (2010). Research ethics: A psychological approach. Lincoln: University of Nebraska Press.

[30]. Strauss, A. \& Corbin, J. (2006).Basics of Qualitative Research: Techniques and Procedures for developing grounded Theory. (2 Ed.). Thousand Oaks: SAGE Publications.

[31]. Tirole, M. (2009). Corporate Governance. Econometria. 69(1)1-35 Zikmund, W. (2010). Business Research Methods. London; Dryden. 